\title{
The Image of Transylvania in the Works of Two Contemporary Romanian Historians. Translation and Related Views on History
}

\author{
Katalin LAJOS \\ Sapientia Hungarian University of Transylvania (Miercurea Ciuc, Romania) \\ Department of Humanities \\ lajoskatalin@uni.sapientia.ro
}

\begin{abstract}
As every inhabited area, culturally Transylvania can also be conceived of mainly as a symbolic space. Starting from its physical, material reality, our perceptions are made up into a subjective image of the area in question. This is the real Transylvania, or rather, the place in connection with which we formulate our ideas and to which we adjust our deeds. This image may seem so real also because it is equally shared by many, occasionally several millions. If many see things in the same way, we could say, this means that they are so in reality, though most of the time we only share prejudices, clichés and misunderstandings" - Sorin Mitu writes. Comparative imagology examines the formation of these collective ideas as well as the issues of identity and attitude to the Other. As a member of the imagology research group at the Department of Humanities of Sapientia Hungarian University of Transylvania, Miercurea Ciuc, Romania, I translated one chapter of Sorin Mitu's volume entitled Transilvania mea [My Transylvania]. During the translation process it became obvious to me that if translation is not only linguistic but also cultural transmission, it is especially true for the translation of historical works and that it would be worth examining whether some kind of rapprochement could be detected between the Romanian and Hungarian historical research of the past decades; if yes, whether this is reflected in the mutual translation of the respective works. ${ }^{1}$
\end{abstract}

Keywords: imagology, history, translation, cultural transmission.

History is a multifaceted term, it is not easy to provide suitable definitions for it; what is considered important in the concept of history and angle from which this highly versatile phenomenon is approached vary by age, trend, discipline,

1 The present study is the edited version of the lecture with the same title held at the $8^{\text {th }}$ International Congress of Hungarology organized in Pécs, Hungary in 2016. 
what is more, also by the historian. Who can pursue history as a discipline? If we only regard the names of disciplines which contain the term "history" (history of politics, culture, philosophy, literature, language, navigation, mentality, international relations, the history of any kind of discipline, etc.), we can see how diverse the range of professionals dealing with particular aspects of history is. ${ }^{2}$ Imagology is a research area that also belongs to this sphere: it examines the mutually formed and distributed images of peoples, ethnic groups and communities not only synchronically, but also diachronically. Thus anyone pursuing a particular discipline can get into contact (and this contact is often unavoidable) with the history of the given field and also of related disciplines.

History, however, is not only the subject of scientific investigations; it is also part of everyday life, it enmeshes our life from the private history and that of the family, through the history of narrower and wider, formal, informal or non-formal communities, to the stories and histories distributed by them. Besides, texts on history are of interest to the wider public as well; what is more, due to their topic, accessibility of approach, smooth style and fortunate timing, particular scientific works may even become bestsellers.

As a member of the imagology research group at the Department of Humanities of Sapientia Hungarian University of Transylvania, Miercurea Ciuc, Romania, I have come into contact with issues of alterity, otherness, images of nations formed about themselves and about others. Within a related research I examined the conflict with, and image of, the other in the Romanian and Hungarian versions of a Romanian type of ballad (Lajos 2011, 60-71). It is also among the objectives of the mentioned research group to translate and thus make accessible for the Hungarian reading public the important volumes and studies of the specialist literature of imagology. As part of this, I translated a chapter of one of Sorin Mitu's books and published it in an omnibus volume containing studies on imagology (Mitu 2016b, 103-131). During the translation process it became obvious to me that if translation is not only linguistic but also cultural transmission, it is especially true for the translation of historical works and that it would be worth examining whether some kind of rapprochement could be detected between the Romanian and Hungarian historical research of the past decades; if yes, whether this is reflected in the mutual translation of the respective works. Romanian and Hungarian languages share the drawback that the scientific products written in these Eastern European languages remain isolated; the one who intends to break out of this confinement is compelled to write in a foreign language of wide circulation or to have his work translated or to write on a topic that attracts

2 Not to mention the names of disciplines which contain the term "historical" or the ones which do not include either form but it is obvious that the historical perspective prevails in them: historical grammar (as well as the history of the distinct parts of grammar, such as historical phonetics, etc.), ethnography, sociology, etc. 
international attention and thus his work will be translated. If we look at the studies of Romanian historians written in foreign languages and the specialist literature used in them, we can see that most of their works have been written in, or translated into, French and French bibliography is dominant. English language bibliographical items have been relatively rare even in the past years. German language is predominant in the Hungarian scientific discourse; English has recently acquired an ever increasing emphasis both as the target language of translation and in bibliographical items; French is almost entirely absent. The situation is slightly different in the very case of Transylvanian scientists, where German turns up on the Romanian side as well and the members of the young generation use English as the language of transmission more and more frequently.

The other condition of rapprochement, in my view, is the common base in the fields of using sources, methodology and theoretical framework. It is hard to maintain a dialogue in other disciplines as well; it is especially difficult in the field of history if its representatives conceive of these issues very differently. Thus it is perhaps also worth examining to what extent the Romanian and Hungarian historians whose works have been translated into the other language are related in terms of methodology.

The history of Transylvania and, less frequently, the studies on the history of the other nation are the shared issues of Romanian and Hungarian historiography that often stir debates, disagreements and conflicts. At first sight it seems that historical works which are mutually translated are the ones that correspond to the view on history of the target language culture , apparently supporting the fact that there are thinkers of similar vein also among the scientists of the other country. Works with different standpoints are either not presented to the target language reading public or stir great dispute among the members of the profession (with an echo in the press), while controversial works are simply not translated. The press reaction to historical works and debates reaches the wider public, beyond the professional sphere, thus forming the image of the particular communities about the other community's attitude, intentions, beliefs and convictions. This certainly shapes the image formed about the other as well as the other community's image and thoughts about their own community. Our research group has considered it important to translate two chapters of Sorin Mitu's book entitled Transilvania mea [My Transylvania] (2006) (and later the translation of the whole volume, which is in progress), because, on the one hand, it is partly, theoretically also related to imagology (see the chapter entitled Comparative Imagology: the Project of a Synthesis Discipline, translated by Judit Pieldner and Zsuzsa Tapodi [Mitu 2016a, 45-83]). On the other hand, some of its chapters (e.g. the one translated by me, entitled Transylvanian Friends and Enemies: Romanians, Hungarians and the Image Formed about Each Other [Mitu 2016b, 103-131]) surprisingly coincide with the Hungarian standpoint, reinforcing the idea that there is a chance of joint 
reflection. When I say "surprisingly," I certainly refer to the prejudice living in the Hungarian common consciousness against Romanian historiography.

I have examined whether the image distributed about the history of the other nation (and about the nation itself), its formation history as well as ideological and methodological background are reflected on among historians after 1989. I would like to highlight two works of this kind, one from Hungarian and one from Romanian historiography respectively. On the Hungarian side, I would mention Nándor Bárdi's plenary lecture held at the RODOSZ conference in Oradea, Romania, on 28-29 April 2016 (conference title: New Challenges and Results in the Transylvanian Historical Research; lecture entitled: Great Topics and Research Projects of Hungarian Specialist Literature after 1989 Dealing with the History of Transylvania, Romania and the Hungarian Minority from Romania). ${ }^{3}$

In this survey the keynote speaker presented the works related to Romania of twentieth century Hungarian historiography by period, topic, school and trend; he spoke about interpretive frameworks and institutional conditions. This results in an image which shows that in the works related to Romania of Hungarian historiography (including both Hungary and Transylvania) the issue of the Hungarian minority from Romania occupies a significant place, and it is mainly in relation to this that the history of the Transylvanian Romanians comes into play. He mentions six works expressly related to Romanian history, written by Hungarian authors (ed. Gáldi-Makkai 1941; Hunya-Réti-Süle-Tóth 1990; Raffai 1989; Miskolczy and Trócsányi 1992; Szász 1993; Balogh 2001). In connection with pluralist traditions the lecturer mentions the topics and phenomena which are common/similar in the history and historiography of the two nations, among others, that in both cases the debunking of national myths and characterologies has commenced; on the Romanian side he mentions the names of Sorin Mitu and Lucian Boia, and that of Balázs Trencsényi on the Hungarian side. It is interesting that in Trencsényi's selected bibliography there appear volumes edited together with Romanian authors who are outstanding (sometimes controversial) figures of Romanian historiography and who promote the rapprochement also discussed here: Sorin Antohi, Dragoş Petrescu, Cristina Petrescu, Marius Turda and Constantin Iordachi, also teaching at the CEU together with Balázs Trencsényi.

The two latter Romanian authors sign a comprehensive study with a thematic bibliography on the perception of Hungary in Romanian historiography (Iordachi and Turda 2000). This text appeared in Hungarian and was translated by Ida Bálintfi and Ottó Bálintfi in the periodical Regio. It was published in Romanian in the same year in the October issue of the periodical Altera from Târgu Mureş. In their opinion, in spite of the changes after the fall of communism, the mutual images

3 The short title of the presentation accessible on the Internet: The Image about Romania of $20^{\text {th }}$ Century Hungarian Historiography. https://www.academia.edu/24874562/Rom\%C3\%A1nia_a_ XX._sz\%C3\%A1zadi_magyar_t\%C3\%B6rt\%C3\%A9net\%C3\%ADr\%C3\%A1sban_v\%C3\%A1zlat 
of the countries in this region have not altered significantly; they continue to be mainly determined by myths and prejudices. While the conflictual relationship at the beginning of the nineties had been replaced by political reconciliation and cooperation by the end of the decade, the images formed earlier live on in the public opinion of the two countries. "Hackneyed commonplaces, prejudices and mutual stigmatization persist in collective memory, in public discourse and - what is even more noteworthy - also in the historians' professional discourse" Iordachi and Turda remark in the introduction $(2000,130)$. The authors outline the historiographic context of the issue and present the work synthetizing the history of the Romanians by three Romanian historians in order to illustrate what types of attitude prevail, on the part of historians, in the image of Hungary in these works. Their conclusion is that in these works the image of Hungary is superficial and it becomes evident that there is no book on the history of Hungary written in Romanian that could be referenced. Not even the highly controversial 1986 book on the history of Transylvania was translated into Romanian (ed. Köpeczi 1986). Besides, the historical discourse on Hungary is limited to Transylvania (Iordachi and Turda 2000, 135).

The representatives of the latest trend taking shape by the end of the decade (who do not belong to just one generation) already examine the theoretical backwardness of Romanian historiography, its insistence on factology as well as the lack of dialogue with the trends of Western historiography. This new discourse has appeared in textbooks, the media and political disputes; however, in each case it met with resistance among the adepts of the nationalist view of history $^{4}$ (Iordachi and Turda 2000, 138). The conclusion of the survey carried out in 2000 is that Romanian-Hungarian political reconciliation (characteristic of that time; it is a question whether it still holds true today) has not brought along the historiographic reconciliation of the two countries; historians with views deviating from the nationalist canon can hardly find their places in spaces that really matter in scientific discourse, for instance, at universities. The reform of Romanian historiography has not been implemented at a theoretical level either. In historiographic works the mutual images of the two countries are still dominated by the nationalist view, though there have also turned up approaches that wish to debunk myths, stereotypes and prejudices. In addition, at the end of the century there emerged groups of young intellectuals whose research projects and interpretive strategies suggest that there is hope to reform this discipline. In his interview published in Székelyhon in March 2016 Zoltán Csaba Novák comes to a similar conclusion as regards the historiography of the present; thus, not much has changed in this field since 2000 (Novák 2016). ${ }^{5}$

4 See the textbook entitled Istorie. Manual pentru clasa a XII-a (History. Textbook for the $12^{\text {th }}$ Grade), edited by Sorin Mitu, which stirred huge scandal in the Romanian media (Mitu 1999). 
Let us continue with the view on history, the attitude towards Romania and, within, Transylvania, of the two Romanian historians discussed in the present paper. I focus in particular on the response their works triggered and the way this reaction manifests - if at all - in the choice of languages these works are translated into. Lucian Boia was born in Bucharest in 1944, thus he belongs to the older generation of historians; with his works, interpretive methods, topics and, not least, his style he earned the status of the "star historian"; his works have been translated into English, German, French, Hungarian, Spanish and Slovak. Still, I would start my argumentation with Sorin Mitu; though he belongs to the younger generation (he was born in Arad in 1965), he takes precedence from the perspective of the present study, as it was through his work that I got in contact with the topic.

The starting point of the conferences on imagology biannually organized by our department was comparative literature; the participants of the conference examined the ways in which the image of the Romanians appeared in Hungarian literature, and vice versa. The bilingual conferences also assumed that these issues needed to be explored based on the knowledge of each other's specialist literature. This is how we got in contact with Andrei Oişteanu's book published both in Romanian and Hungarian, which deals with the issue of the imaginary Jew $(2001,2005) .{ }^{6}$ At the same time, we also came across Sorin Mitu's volume (Mitu 2006), which, through its assumed subjectivity, Transylvania-related topic, knowledge and use of international specialist literature as well as consciously applied imagological viewpoints proved to be a valuable tool for our research group. Concurrently, we thought that its style and readability also made it worth transmitting the book to the Hungarian public (professional and "lay", interested in the topic) not knowing the Romanian language. The fact that historiographic texts approaching in a balanced and objective manner a delicate issue that has been the buffer zone of Romanian-Hungarian historiography for long decades (slowly amounting to a century) can be read in full length in their mother tongue can play a role in establishing closer ties between the two communities (in terms of type and language). ${ }^{7}$

Romanian Academy, belongs to the younger generation of historians and thinks that the shift that can be detected in a few issues in the present state of historiography can partly be assigned to the fact that there is indeed a tendency of rapprochement, there is an ever more systematic communication between young Romanian and Hungarian historians; the members of this generation are mutually present in each other's institutions in the course of further trainings, doctoral and postdoctoral studies. The question remains, however, when these approaches transgressing the boundaries of classical and dogmatic Romanian historiography will become part of common consciousness (e.g. education).

6 Oisteanu's book originally appeared in 2001, it has had several editions ever since (in 2005 it was also published by Humanitas, in 2012 by Polirom, Iaşi); in 2005 it was published in Hungarian at Kriterion, in Zsuzsa Hadházy's translation.

7 Alina Mungiu-Pippidi noted in 1999, "which is the issue that arouses the most primitive feelings in us if not Transylvania? This region is the core of the political disputes, nation and identity building endeavours of the two nations, upon which the self-esteem of all of us depends" (1999, 11-12). 
The volume opens with an eleven-page introduction presenting the author's involvement and personal relation with the topic (in what sense the discussed topic is "my Transylvania"), his attitude towards historiographic trends, the AustroHungarian domination's effects on Transylvanian culture, his family traditions' relation to the East and to the West, as well as his personal intellectual journey from Romanian nationalism (defining his childhood) to intellectual liberalism. In Romanian humanities this type of self-reflexive attitude to a research topic is unusual. After outlining the different chapters of the book, he also addresses the issue of spelling Hungarian proper names specifying that "in the spirit of grammatical civility" and according to the traditions of Transylvanian Romanian orthography the surname precedes the first name. Reading such an introduction, the Hungarian reader speaker of Romanian language feels - might feel that the volume is probably not only about the author's, but also about the reader's, the Hungarian reader's Transylvania, something refreshing in the context of our prejudices with reference to Romanian historiography.

To offer you a taste of the structure of the book to be translated: it consists of six chapters, the first of which analyses the relevant topics of Romanian historiographic discourse and refers to bibliography relevant to the topic. Among the works on the status of historians and historiography we will find authors and works also mentioned in the present study such as Sorin Antohi, Constantin Iordachi, Trencsényi Balázs and others (Murgescu 2000; Zub and Antohi 2002; Iordachi and Trencsényi 2000). The topic that seemed so relevant at the millennium has not lost its relevance six years later either, and the author of any historiographic work cannot avoid reflecting upon the parallel existence of the conservative group with its mentality built on the basis of communist nationalism and the liberal one whose mentality nears modernism. This is also the chapter addressing the problems of identity, the relations among archives, the public and historians, the methodology of comparative imagology, ${ }^{8}$ as well as the image of the Other in symbolic geographies.

The second chapter deals with issues where Transylvania played the role of a buffer zone between cultures: the decentralization of Transylvania, its autonomy, the debate on its federative reorganization starting from 1997, the conflicts with reference to the University from Cluj-Napoca, and the ones in connection with the 1848 revolution. The third chapter discusses the fundamental topics of the history of modern Transylvania: concepts such as the homeland, Europe, revolution and holiday. The titles of subchapters ("The Structure of the Concept of Homeland in the Case of Romanians from Transylvania"; "The Image of Europe for Romanians from Transylvania"; "Why the Romanian Peasants Stirred a Revolution"; "The Media and the (Counter)Revolution"; "Holidays, Alterity and

8 This is part of the chapter also published in translation, as has been mentioned earlier (Mitu 2016b: 45-83). 
Social Conflict") well illustrate the thread of the chapter and perhaps they also provide an insight into its approach. ${ }^{9}$ The fourth large chapter uses the tools of the history of mentalities to discuss issues of Transylvanian history: the status of love in the mentality of Transylvanian peasantry, the phenomena of ecclesiastical celibacy in the Greco-Catholic Church, the image of the Austrian emperor in the minds of Transylvanian women and national feelings, as well as Avram Iancu's Hungarian lovers are the topics discussed in the chapter. The fifth chapter bears the title "Transylvanian Friends and Enemies: Romanians, Hungarians and their Image of Each Other." Out of the eight subchapters of this part I have translated three, and maybe already the title in itself explains why I have chosen this chapter to translate: it uses the tools of imagology to discuss the very topic that interests us, Hungarians from Romania and from elsewhere, the most. Based on the Hobsbawm theory of "invented tradition" it attempts to create an introduction to a Romanian-Hungarian imagological history (this being the title of the first subchapter), while the following two subchapters comprise the historical analysis of the stereotypical image of Hungarians in the Romanian mentality, ${ }^{10}$ as well as of the image of Romanians in Hungarian consciousness (the titles of the subchapters are: "Romanian Stereotypes about Hungarians" and "Romanians in the Eyes of Hungarians: the Creation of an Ethnic Image"). The further subchapters deal with the following: the presence of the Horea-uprising in Hungarian historiography, the analysis of the Unitarian minister Sándor Ürmösy's journals about his travels in Wallachia and the image of Romanians created in the journal, the point of view with reference to Romanian history conveyed by the historiographic works of László Kőváry, the presentation of Mór Jókai’s journalistic and literary works on the topic of Romanians, the image of Romanian women in Hungarian works, and the analysis of the autobiographical work of József Dálnoky Incze about the 1848 Revolution. The topic of the sixth large chapter is the image of the West for Romanians from Transylvania: the image of the French in the mentality of the medieval Transylvanian peasantry, the appearance of this image in official propaganda and in folk mentality, the image of Italy in the public opinion of the 1850s, relations between the Carbonari movement and the Romanian revolutionary movement, the nineteenth century relations of the Irish model and the Romanians from Transylvania, the image of the American and within it that of Benjamin Franklin for Romanians from Transyvania. The first paragraph of the

9 In the third subchapter the author - being not the only one among Romanian historians to do so - adds an almost one-page-long footnote discussing the reasons why the events denoted as the 1848 Romanian revolution cannot be called a revolution, and what other terms could be used for these historical events. The title of the fourth chapter also alludes to the same thing.

10 The first sentence: "The images of Romanians about Hungarians constitutes a topic missing almost entirely from the literature of our field." A footnote also expresses the author's intention to conduct a wider research in this respect, an endeavor that faces the primary obstacle of the lack of prior research (Mitu 2006, 229; in Hungarian: Mitu 2016b, 109). 
closing remarks returns to raising awareness to the theoretical framework, and states the following:

We live under a generous epistemological constellation. Our research is led by the most varied models, questions and theories teaching us about how to search for the thousands of faces of the truth. This far too wide space also hides traps, and undoubtedly it has an unsettling effect on those historians who got used to their so comfortably respectable truths. However, no doubt that methodological pluralism and relativism causes one important satisfaction: the joy of unlimited free thinking, the delight that we can sail freely the seas opened up in front of our curiosity. (Mitu 2006, 431) ${ }^{11}$

From the point of view of translation those chapters prove to be a particularly difficult task where the author quotes lyrical folkloric texts to illustrate the different images of Otherness apparent in folk mentality. Such chapters and subchapters are yet to be translated and most probably they will lead to conclusions interesting also from the perspective of translation theory and practice.

I have considered it important to add to the present paper these review-like two pages to illustrate what type of text we consider worth translating. I believe, namely, that it is extremely important to provide access to larger Romanian works concerning the common topics of Romanian and Hungarian history not only for a narrow professional readership, but also for the larger public, something that may be ensured first of all through their Hungarian translation.

Among the Romanian historians the most popular today and out of the older generation whose most works have been translated to Hungarian as well is Lucian Boia, belonging to the myth-deconstructing historians, something that makes him extremely popular among both Romanian and Hungarian readers interested in history. In addition, his style is also highly readable and lively, it is free of the usual heaviness of the Romanian scientific discourse, it almost offers itself up for translation. ${ }^{12}$ The bookshop of the Guttenberg Publishing House from Miercurea Ciuc distributes Boia's works both in their Romanian and Hungarian versions and to my enquiry with reference to their popularity among the Hungarian reading public, the owners of the bookshop informed me that there has been a high demand for them among both Hungarians from Hungary and from Transylvania, some of the buyers requesting books by their titles, others asking for Boia-works translated into Hungarian. Although only a narrow layer of the readers is characterized by this phenomenon, it is still significant: it is the interest manifested of the already narrow layer of those who buy books. The promotional strip of paper around Boia's volume entitled Winners and Losers - A Reinterpretation of World

11 My own translation.

12 See the list of Lucian Boia's works translated into Hungarian in the Works Cited. 
War I, says: "World War I through the Eyes of the Romanian Star-Historian." In his works he manifests a relativist perception of history, and although such a perspective has long been accepted in Western Europe, it was a novelty in Romanian historiography in the second half of the nineteen-nineties. In some of this works he examines those axioms of Romanian historiography the questioning of which was for decades taboo and even today this approach has caused a stir among nationalist circles. However, this breaking down of taboos has largely contributed to the development of a dialogue between the Romanian and Western historiography and to the bridging of the gap between the conflicting images of history of the Romanian and the Hungarian reading public.

Among the revised myths we find, for example, the Daco-Romanian continuitytheory, the myth surrounding the national unification act of Voivod Mihai Viteazul, the myth of nationalism, the myth of Romanian unity, the myth of the Romanian spirit and national particularity, the myths of the different historical ages with reference to foreign nations (the image of the French, the Germans, the Roma, the Jews, the Hungarians in the public opinion of the given era and of today), the myths of the figures in the national pantheon. ${ }^{13}$ Out of the topics listed here almost all touch upon the "sensitivity" of the Hungarian minority from Romania, to mention just a few examples: with reference to the historical affiliation of Transylvania, dogmatic historiography calls the Hungarians from Transylvania immigrants on the basis of the theory of continuity and in times of ethnic crises this is the basis upon which they are sent back to Asia by extremist public speeches. Mihai Viteazul's act of 1599-1600 through which he united the rule of the territories of Moldova, Wallachia and Transylvania in one hand appears in communist historiography as the first unification of Romania, a proof of the fact that the pursuit for the unification of the country and an awareness of Romanian unity existed already in the sixteenth century, that already in those times Transylvania was a Romanian country, thus this date also figures as a national holiday in the Romanian calendar.

Boia, Mitu and more and more of the Romanian historians have been demolishing the walls of these myths, they have pointed out their mythic character, they have positioned them in that historical-ideological context in which they have become myths, they have followed their changes through the different historical ages, and they have also analyzed the functions these myths fulfill today (see also Mitu 1998, 2008). A balanced approach, and the objective handling of historical documents have become more and more important also for the Romanian public. Also the Romanian readers' reviews of such books and articles show that there is demand for such works and such endeavors are positively appreciated. Thus, it is highly important to make them accessible for the Hungarian reading public as well. And in this respect the translator(s) have/may have an important role, as well as the existence of a supporting medium and institutional strategy.

13 The list of these myths follows the structure of Boia's 1977 volume (in Hungarian Boia 1999). 
Historian Csaba Zoltán Novák considers these to be of utmost importance in the case of larger, monographic works, and this seems to be happening in the case of more popular historians. Among the Romanian publishing houses the Humanitas from Bucharest and the Polirom from Iaşi are the ones where one can detect a conscious undertaking for the publication of these works. Among the Hungarian publishing houses from Romania the Koinónia from Cluj-Napoca and the Kriterion publishing house with headquarters in Bucharest and Cluj-Napoca have been publishing these works in Hungarian. Among the latest generation of Hungarian historians from Romania there are those who ensure themselves that soon upon their publication their works appear also in Romanian or English, given that within the group of professionals publication in English also helps the exchange of information. Thanks to this there is an increase in the number of those young Romanian historians who reference in their works the studies published by their Transylvanian Hungarian colleagues. This is first of all true with reference to the history of contemporary times. For the larger Romanian reading public, however, only works translated into Romanian are accessible, and this would be of primary importance for the bridging of the gap between the two different images of history not only within the limited group of professionals but also among the larger public interested in these issues. I cannot detect any editorial or research forum that would have taken on this task. Thus, the process seems somewhat one-sided: there have been made primarily Hungarian (and within that Transylvanian Hungarian) effort for the transmission of the significant achievements of Romanian historiography towards the larger public. From the Romanian side there seems to be lesser tendency on the part of publishing houses to publish the achievements of Hungarian historiography in Romanian language (first of all press news report on the more important publishing events, the manual entitled The History of Szeklerland [ed. Hermann 2012] has been translated into Romanian, but it does not clearly state who its translator was $\left.{ }^{14}\right)$.

And finally, we have to state the fact that the most powerful tools for the demolishing of prejudices, stereotypes and taboos are school history classes. If these perspectives infiltrated into education, then there would be a chance for the true transmission of historical images. And this might be the most difficult thing to do: what is needed is a change of perspective for university professors, in the curricula, in manuals and for teachers, and such a process is a slow one even in the case of emotionally-ideologically less affected subjects.

I am commencing my paper with the statement of Hungarian historian from Cluj-Napoca Radu Lupescu, professor at Sapientia Hungarian University from Transylvania made in 2013, in order to illustrate how the above issue is on the mind of many, and in the process of its slow solutioning (for I do believe that 
that is what the future will bring) languages, linguistic mediation will play an important role:

Transylvanian historians are worthy partners of both the Romanian and the Hungarian community of professionals. Since the system change there have been published a whole series of so far missing Transylvanian reference books. The only real problem consists in the fact that reference books on the past of Transylvania are only published in Hungarian, thus they are not accessible for the Romanian language professionals. [...] this is a transition state, upon the publication of Hungarian reference books there will soon come the time when the Transylvanian past will figure emphatically in English language literature and will also be accessible in Romanian. We could step out of this vicious circle with the collaboration of Hungarian historians from Transylvania if our profession takes the role of the bridge between Romanian and Hungarian historiography seriously. Lucian Boia's successful books may prepare the ground for the opening. There is no other path, for - as Boia phrases it - societies built on lies have no future. (Lupescu qtd. in Makkay 2013)

In implementing the recognized bridge-role of Transylvanian Hungarian historiography translators may be of assistance, who would not only translate the important works of Romanian science into Hungarian, but would also translate into Romanian those works of Hungarian science that could play a role in making this branch of science into the space of dialogue.

Translated by Judit Pieldner and Boróka Prohászka-Rád

\section{Works Cited}

Balogh, László. 2001. Románia története. [The History of Romania.] Budapest: Aula Kiadó Kft.

Bárdi, Nándor. 2016. Erdély, Románia és a romániai magyar kisebbség történetével foglalkozó 1989 utáni magyar nyelvú szakirodalom nagy témái és a kutatási programok. [Great Topics and Research Projects of Hungarian Specialist Literature after 1989 Dealing with the History of Transylvania, Romania and the Hungarian Minority from Romania.] (Keynote lecture held at the Transylvanian conference of PhD students of history on 28-29 April 2016) https://www.academia.edu/24874562/Rom\%C3\%A1nia_a_XX._sz\%C3\%A1 zadi_magyar_t\%C3\%B6rt\%C3\%A9net\%C3\%ADr\%C3\%A1sban_v\%C3\%A1z lat_ (Last accessed 30 June 2016) 
Boia, Lucian. 1997. Istorie şi mit în conştiința românească. [History and Myth in Romanian Consciousness.] Bucharest: Humanitas.

Boia, Lucian. 1999. Történelem és mítosz a Román köztudatban. [History and Myth in Romanian Consciousness.] Trans. János András. Bucharest-ClujNapoca: Kriterion.

Boia, Lucian. 2012. De ce este România altfel? [Why Is Romania Different?] Bucharest: Humanitas.

Boia, Lucian. 2013. Sfârşitul occidentului. [The End of the West.] Bucharest: Humanitas.

Boia, Lucian. 2014a. Miért más Románia? [Why Is Romania Different?] Trans. István Rostás-Péter. Cluj-Napoca: Koinónia.

Boia, Lucian. 2014b. A Nyugat hanyatlása. [The End of the West.] Trans. István Rostás-Péter. Cluj-Napoca: Koinónia.

Boia,Lucian.2014c.Primulrăzboimondial.Controverse, paradoxuri,reinterpretări. [The First World War. Controversies, Paradoxes, Reinterpretations.] Bucureşti: Humanitas.

Boia, Lucian. 2015. Vesztesek és győztesek - Az elsó világháború újraértelmezése. [Losers and Winners - Reinterpretation of the First World War.] Trans. Zoltán Tibori Szabó. Budapest: Cser.

Gáldi, László and László Makkai. 1941. Románia története: különös tekintettel az erdélyi románokra. [The History of Romania with Special Regard to Transylvanian Romanians.] Budapest: Magyar Történelmi Társulat.

Hermann, Gusztáv et al, ed. 2012. A székelység története. Kézikönyv és tankönyv az általános iskolák VI. és VII. osztályai (valamint minden érdeklődó) számára. [The History of the Szeklers. Manual and Textbook for $6^{\text {th }}$ and $7^{\text {th }}$ Grades of Lower Secondary Schools (and for Anyone Interested).] Miercurea Ciuc Sfântu Gheorghe - Odorheiu Secuiesc: Harghita County Tradition Preserving Resource Centre Harghita County Council/Covasna County Council/Covasna County Cultural Center.

Hunya, Gábor, Tamás Réti, Andrea R. Süle and László Tóth. 1990. Románia 19441990 (Gazdaság- és politikatörténet). [Romania 1944-1990 (Economic and Political History).] Budapest: Atlantisz.

Iordachi, Constantin and Marius Turda. 2000. "Reconciliere politică versus discurs istoric: Percepția Ungariei in istoriografia românească, 1989-1999.” ["Political Reconciliation vs Historical Discourse: The Perception of Hungary in Romanian Historiography, 1989-1999.”] Altera vol. VI no. 14 (October): 153-174. In Hungarian: Iordachi, Constantin and Marius Turda. 2000. "Politikai megbékélés versus történeti diskurzus: az 1989-1999 közötti román történetírás Magyarország-percepciója.” Trans. Ida Bálintfi and Ottó Bálintfi. Regio-Kisebbség, politika, társadalom vol. 11. no. 2: 129-157. 
Iordachi, Constantin and Balázs Trencsényi. 2000. "A megújulás esélyei: a román történetírás tíz éve (1989-1999)." ["The Chances of Renewal: Ten Years of Romanian Historiography (1989-1999).”] Replika. Társadalomtudományi Folyóirat no. 41-42 (November): 165-195.

Köpeczi, Béla, ed. 1986. Erdély története három kötetben. [The History of Transylvania in Three Volumes.] Budapest: Akadémiai.

Lajos, Katalin. 2011. "Konfliktusok és konfliktusokozók a Miorița népballadában.” ["Conflicts and Conflict Triggerers in the Folk Ballad Miorița."] In Kapcsolatok, képek. Imagológiai tanulmányok [Connections, Images. Studies on Imagology], eds. Levente Pap and Zsuzsa Tapodi, 60-71. Miercurea Ciuc: Status.

Makkay, József. 2013. “A román történelem hiányzó ezer éve.” [“The Missing One Thousand Years of Romanian History.”] Erdélyi napló February 8. https://erdelyinaplo.ro/aktualis/riportok/a_roman_tortenelem_hianyzo_ezer_ eve (Last accessed 16 July 2016)

Miskolczy, Ambrus and Zsolt Trócsányi. 1992. A fanariótáktól a Hohenzollernekig: társadalmi hanyatlás és nemzeti felemelkedés a román történelemben, 17111866: két tanulmány. [From the Fanariots to the Hohenzollerns: Social Decline and National Rise in Romanian History, 1711-1866: Two Studies.] Budapest: ELTE.

Mitu, Sorin. 1998. "Illúziók és valóság Erdélyben." ["Illusions and Reality in Transylvania."] Trans. Júlia Singer. http://www.c3.hu/scripta/beszelo/98/09/ 06mitu.htm (Last accessed 15 July 2016)

Mitu, Sorin, ed. 1999. Istorie. Manual pentru clasa a XII-a. [History. Textbook for the $12^{\text {th }}$ Grade.] Bucuresti: Sigma.

Mitu, Sorin. 2006. Transilvania mea. Istorii, mentalități, identități. [My Transylvania. Histories, Mentalities, Identities.] Iaşi: Polirom.

Mitu, Sorin. 2008. "Szakítás a nacionalizmussal.” ["Break With Nationalism.”] Trans. Erzsébet Kántor. Korunk vol. 19. no. 1: 25-27. (January) http://korunk. org/?q=node/8773 (Last accessed 15 July 2016)

Mitu, Sorin. 2016a. "Összehasonlító imagológia: egy összefoglaló tudományág terve." ["Comparative Imagology: the Project of a Synthesis Discipline."] In Imagológiai olvasókönyv [Imagology Reader], ed. Zsuzsa Tapodi, trans. Judit Pieldner and Zsuzsa Tapodi, 45-83. Cluj-Napoca: Scientia.

Mitu, Sorin. 2016b. "Erdélyi barátok és ellenségek: románok, magyarok és egymásról alkotott képük." ["Transylvanian Friends and Enemies: Romanians, Hungarians and the Image Formed about Each Other.”] Trans. Katalin Lajos. In Imagológiai olvasókönyv [Imagology Reader], ed. Zsuzsa Tapodi, 103-131. Cluj-Napoca: Scientia.

Mungiu-Pippidi, Alina. 1999. Transilvania subiectivă. [Subjective Transylvania.] Bucharest: Humanitas. 
Murgescu, Bogdan. 2000. A fi istoric în anul 2000. [To Be a Historian in 2000.] Bucharest: ALL Educational.

Novák, Csaba Zoltán. 2016. "A román történelemszemlélet dogmáiról.” [“On the Dogmas of the Romanian Historical View."] https://eurocom.wordpress. com/2016/03/04/a-roman-tortenelemszemlelet-dogmairol-szekelyhon-ro/ (Last accessed 10 July 2016)

Oişteanu, Andrei. 2001. Imaginea evreului în cultura românească. Studiu de imagologie în context est-central european. [The Image of the Jew in Romanian Culture. An Imagological Study in East-Central European Context.] Bucharest: Humanitas.

Oişteanu, Andrei. 2005. A képzeletbeli zsidó a román (és a kelet-közép-európai) kultúrában. Imagológiai tanulmány. [The Imaginary Jew in Romanian (and East-Central European) Culture. An Imagological Study.] Trans. Zsuzsa Hadházy. Cluj-Napoca: Kriterion.

Raffai, Ernő. 1989. Vajdaságoktól a Birodalomig. Az újkori Románia története. [From Voivodeships to the Empire. The History of Modern Age Romania.] Szeged: JATE.

Szász, Zoltán. 1993. A románok története. [History of the Romanians.] Budapest: Bereményi.

Zub, Alexandru and Sorin Antohi. 2002. Oglinzi retrovizoare. Istorie, memorie şi morală în România. [Rear-View Mirrors. History, Memory and Morals in Romania.] Iaşi: Polirom. 